\title{
Geomorphic Indices of Tectonic Activity Through the Analysis of the Drainage Systems in Pera Magroon Anticline, Northeastern Iraq
}

\author{
Sarah K. Mohammed \\ Department of Geology \\ College of Science \\ University of Baghdad
}

\author{
Manal Sh. Al-Kubaisi \\ Department of Geology \\ Colleage of Science \\ University of Baghdad
}

\author{
Azhar Kh. Bety \\ Department of Geology \\ Colleage of Science \\ University of Sulaimani
}

(Received 12/8/2018 ，Accepted 5/11/2018)

\begin{abstract}
The study area (Pera Magroon) is located within Kurdistan Region, Sulaimaniyah Governorate, north and northwest of Sulaimaniyah city northeastern Iraq. Arc GIS, hydro tool is used to extract the drainage network in the area under study by using digital elevation models (DEM). The study area is covered by dendritic and parallel drainage patterns and divided into twenty sub-basins.

Three geomorphic indices, Mountain-front sinuosity (Smf), Stream-gradient index (SL) and Valley floor width-valley height ratio $(\mathrm{V} f)$ were calculated for subbasins.

Through averaging these three indices, we obtained index of active tectonics (IAT). The values of the index were divided into classes to define the degree of active tectonics. Therefore, relative tectonic activity is calculated and their values are classified and analyzed in three groups. The sub-basins were identified as very high, high and moderate levels.
\end{abstract}

Key words: Geomorphic index, Drainage basin, Tectonic activity, GIS, DEM.

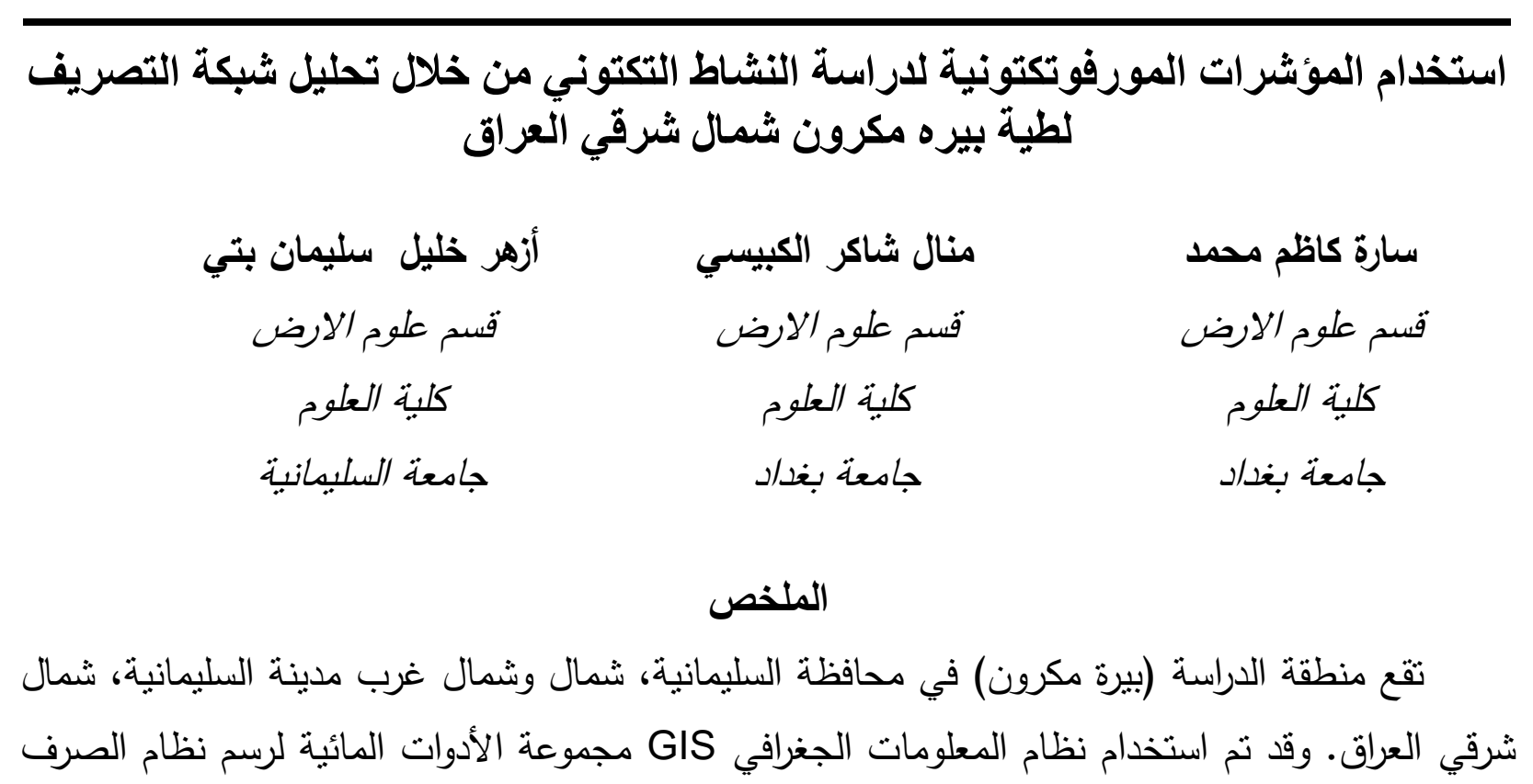




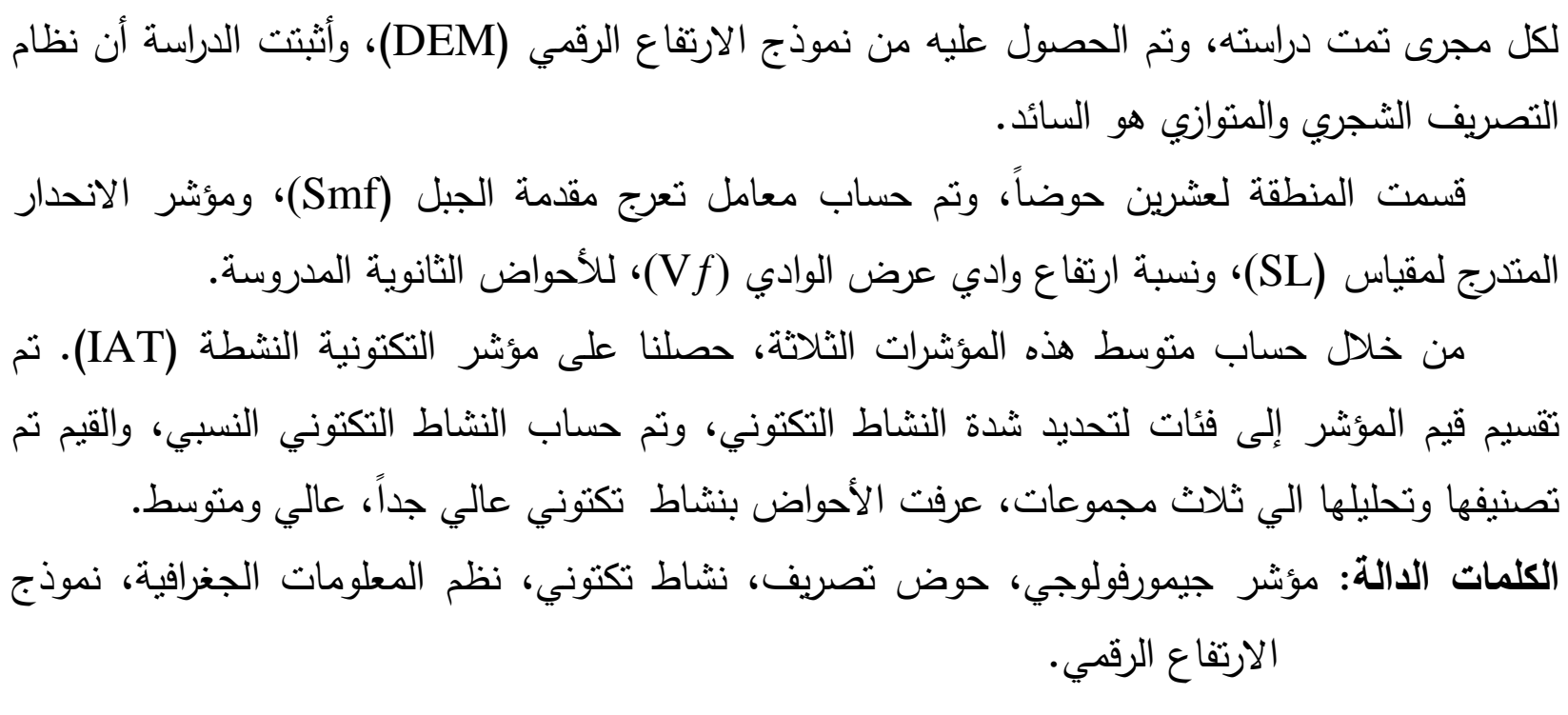

\section{INTRODUCTION}

Pera Magroon anticline is a huge asymmetrical doubly plunging anticline within the High Folded Zone of the Zagros Fold Thrust Belt. The anticline is located about $10 \mathrm{~km}$ northwest of Sulaimani city (Jassim and Goff, 2006).

Geomorphologic indices are useful for identification of areas that underwent rapid tectonic deformation. Each of these indices provides a relative classification of the intensity of active tectonics. For a specific area, using the several indices rather than an index provide more meaningful results (Keller and Pinter, 2002).

Rivers are an important feature of most landscapes; and Landscape in tectonically active areas results from a complex integration of the effects of vertical and horizontal motions of crustal blocks and erosion or deposition by surface processes (Burbank and Anderson, 2001).

This study presents a method for evaluating relative active tectonics based on geomorphic indices useful in evaluating morphology and topography. These used indices include: Mountain-front sinuosity (Smf), stream length-gradient index (SL), and ratio of valley-floor width to valley height (Vf).

\section{Aim of study}

Applying remote sensing techniques by using image data process and geographic information systems (GIS) in the processing of spatial data in order to assess the tectonic activity of the study area by using the Geomorphic indices.

\section{Geographical location}

The study area is located at the northern part of Iraq within Kurdistan Region, Sulaimaniyah Governorate, northwest of Sulaimaniyah city between (45 9' 00" $\left.45^{\circ} 18^{\prime} 00^{\prime \prime} \mathrm{E}\right)$ and ( $\left.35^{\circ} 43^{\prime} 00^{\prime \prime} 35^{\circ} 47^{\prime} 00^{\prime \prime} \mathrm{N}\right)$, It comprises the Pera Magroon anticline (Fig.1). 


\section{Tectonic setting}

The Pera Magroon anticline is located within the northeastern part of Iraq, it's the outer part of the Arabian plate.

There are several major and minor anticlines and thrust faults existing within the High Folded Zone, the Pera Magroon anticline is located within these zones.

These major anticlines are considered as complex structures due to the deformation which had been caused by the collision of the Arabian plate with the Iranian plate It was intermittently uplifted in Cretaceous and Paleocene and strongly deformed in the Late Neogene causing regional compressive horizontal forces in NE-SW direction, leading to folds trending in NW - SE axial direction (Fouad, 2010), (Fig. 2).

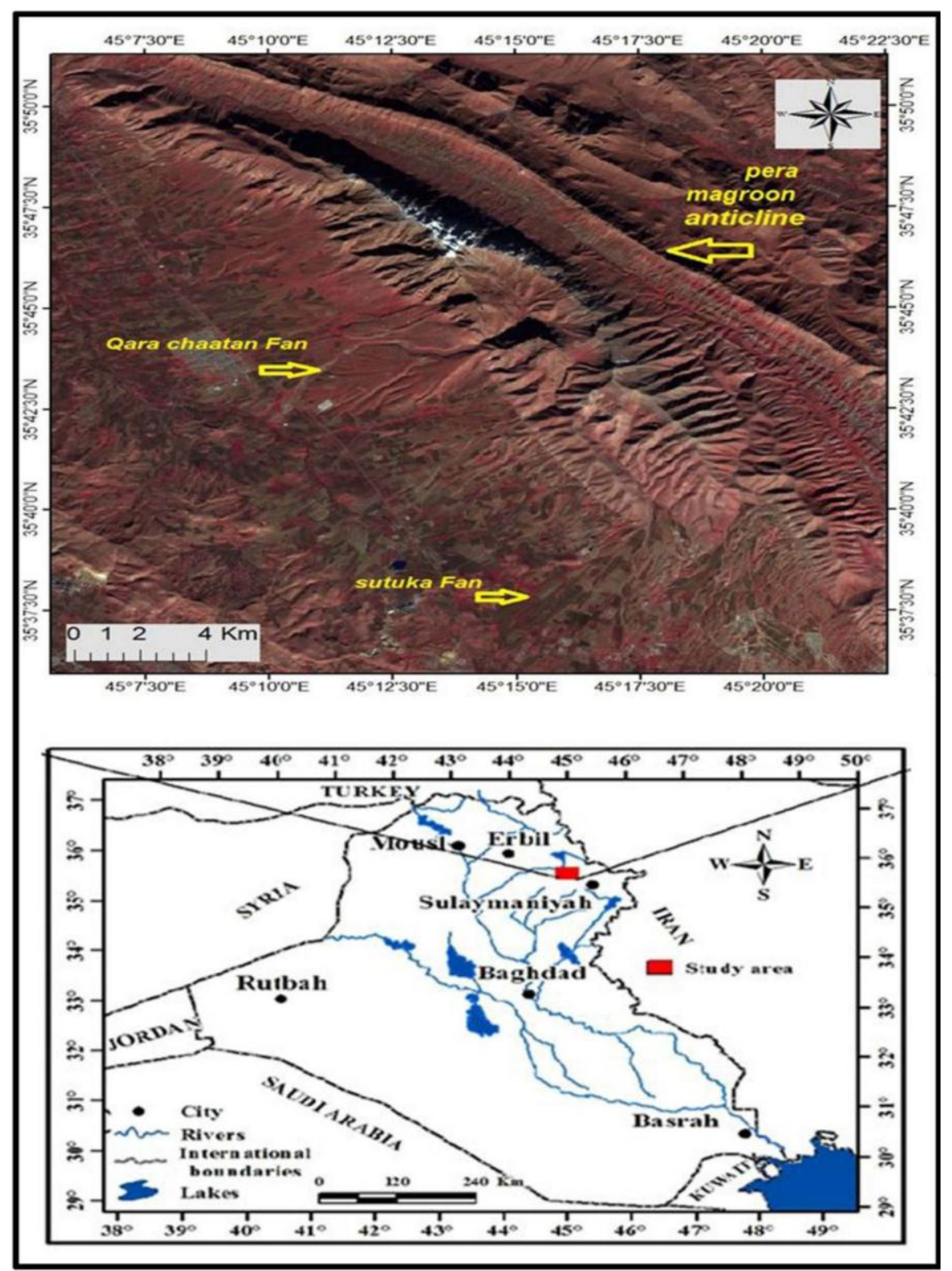

Fig. 1: Location of Study Area (Sentinel2 Image). 


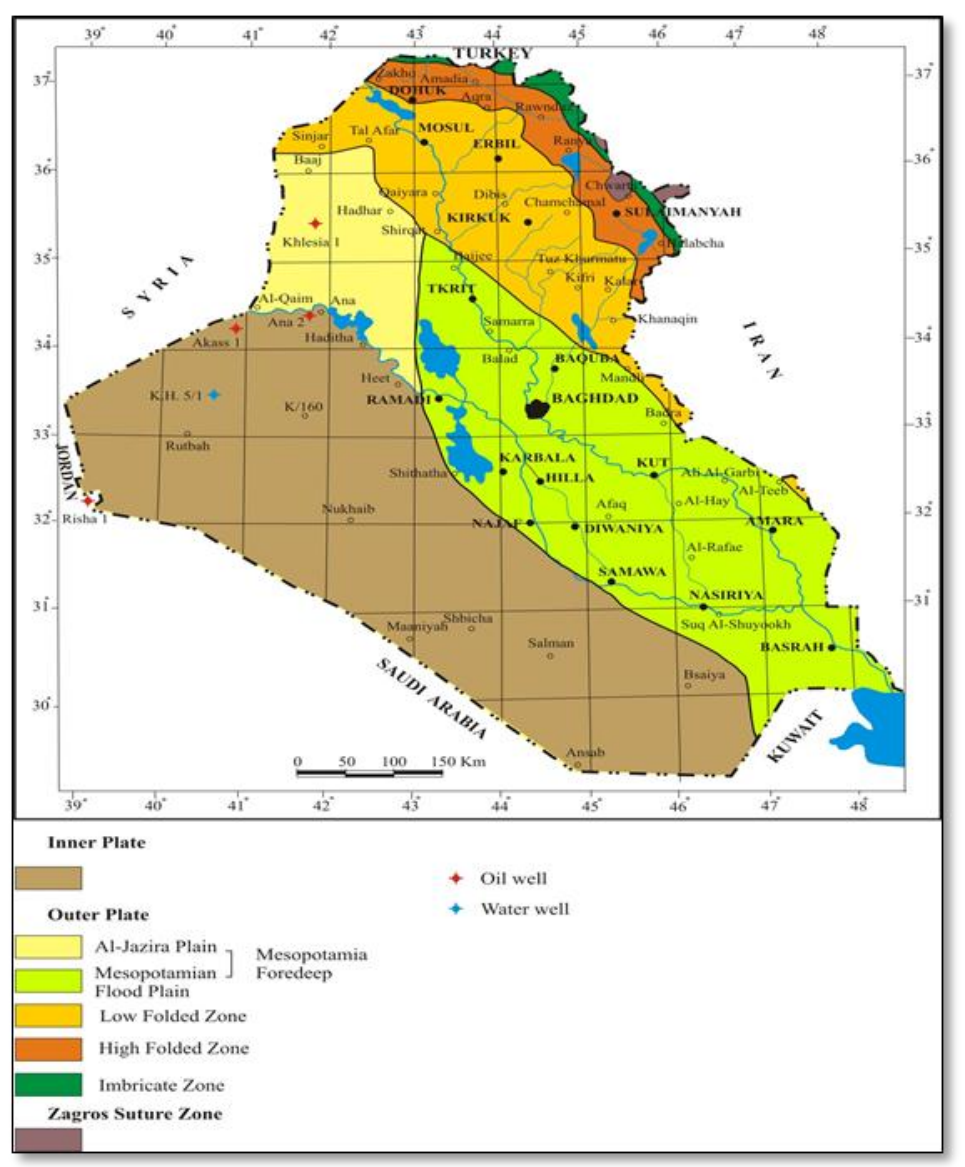

Fig. 2 : Tectonic Map of Iraq (After Fouad, 2010).

\section{Geological Setting}

The area of study contains many stratigraphic units appeared as outcrop, ranging from Lower Cretaceous to Recent age, those formations are drawn from oldest to youngest as in (Fig .3):

1- Sargelu Formation (Middle Jurassic): The total concentration of the Sargelu structure is about $120 \mathrm{~m}$ in Sargelu village. It consists of medium tough to tough, dark grey to black, thickly bedded in the lower $(50 \mathrm{~m})$ becomes thinly to medium bedded, in the upper part, fine to medium crystalline limestone and dolomitic limestone, with thin horizon of dark papery shale and bituminous limestone.

2- Chia Gara Formation (Late Jurassic - Early Cretaceous): The Formation consists of an interchange of thinly bottomed limestone and shale rich in ammonites. The maximum thickness is $232 \mathrm{~m}$.

3- Balambo Formation (Early Cretaceous): The formation consists of thinly bottomed limestone with intercalations of dark grey marl and or shale. The exposed thickness of this formation in the type section is $762 \mathrm{~m}$.

4- Sarmord Formation (Early Cretaceous): The total thickness of the formation is $450 \mathrm{~m}$, it consists of alternation of marl and limestone. 
5- Qamchuqa Formation (Early Cretaceous): The formation consists of dark brown dolomite whereas the latter is quietly bedded inside and has light grey limestone.

6- Kometan Formation (Early Cretaceous): It consists of white limestone that is thin and well bedded, but is relatively hard and slightly stroked with marl. The formation provides the alluvial fans with sediments of medium particles sized.

7- Shiranish Formation (Campanian): It consists of blue well bottomed out thinly marl and marly limestone. The thickness of the formation varies between 200-220 m.

8- Tanjero Formation (Maastrichtian): The formation consists of an interchange of dark green and yellowish green shale, clay, mud and conglomerate.

9- Quaternary Deposits (Pleistocene-Holocene): Quaternary sediments cover a large part of the territory of the study area, particularly in the west and southern limbs of it, and also occupy the lowland region like syncline, slopes, and plains. It seems that it is the important sediments in the study area. Alluvial fans with fluvial deposits represent most of the Quaternary deposits (Sissakian and Fouad, 2014).

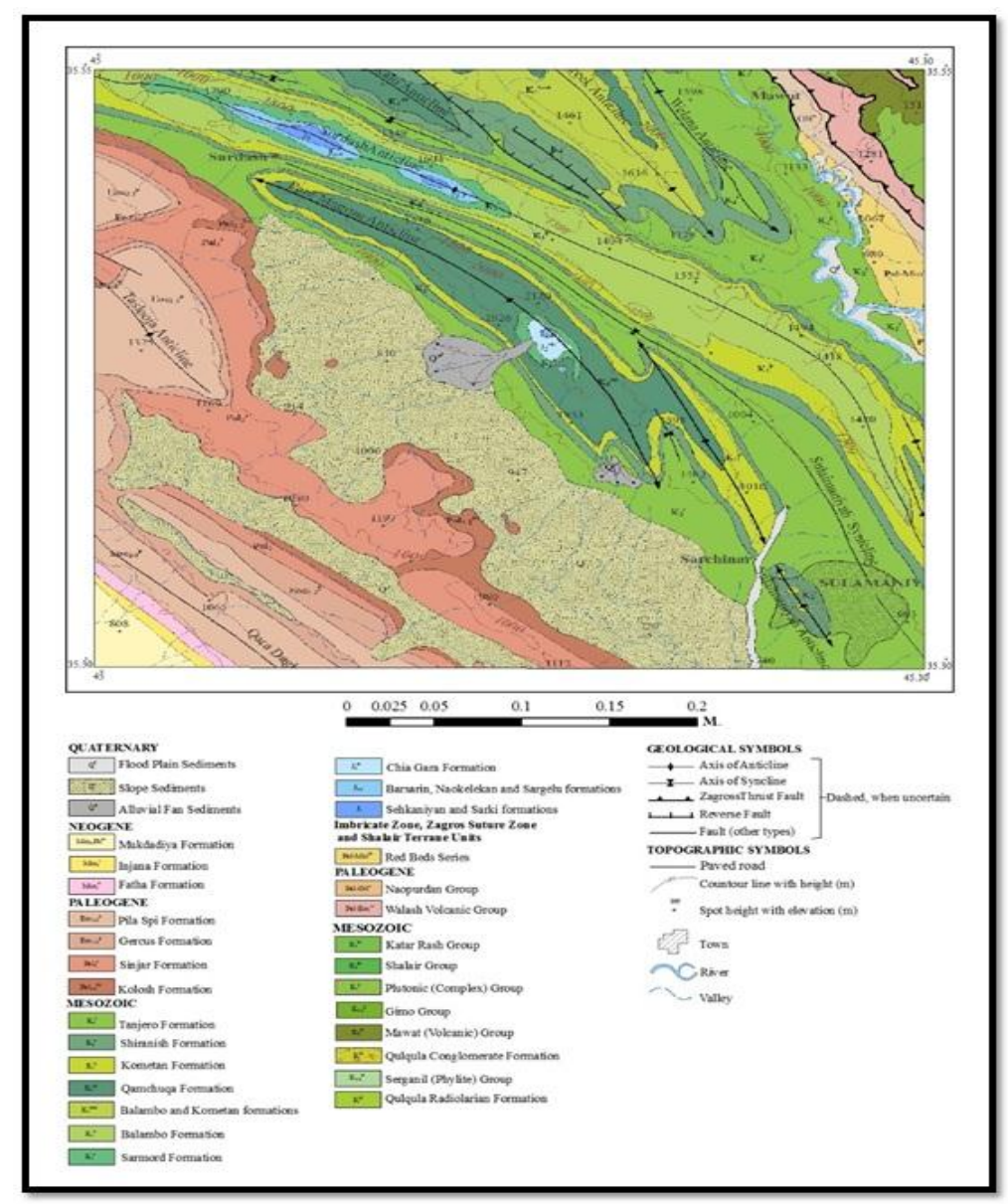

Fig. 3: Geological Map of Study Area (Sissakian and Fouad, 2014). 


\section{MATERIALS AND METHODS}

The digital elevation model (DEM), sentinel2 image and image processing software (Arc GIS V 10.3) are used to calculate geomorphic indices, which are suitable for assessment of tectonic activity of Pera Magroon anticline.

Geomorphic indices are calculated in study area by using topographic data. On the other hand, the area is divided into 20 sub-basins, based on digital elevation model for each one, indices were calculated, and then all of the indices were combined to obtain index of active tectonics (IAT) by new method.

\section{Drainage networks:}

A strong tectonic control on drainage lines were reflected in some landscapes. Structural and tectonic features, such as joints, faults, and lineaments, that may produce essentially straight rivers, i.e. rivers with limited meander development (Arian and Aram, 2014). Depending on the DEM, the drainage network of the area under investigation was extracted by using GIS technology; Mostly the area of study was covered by dendritic and parallel patterns as shown in (Fig. 4).

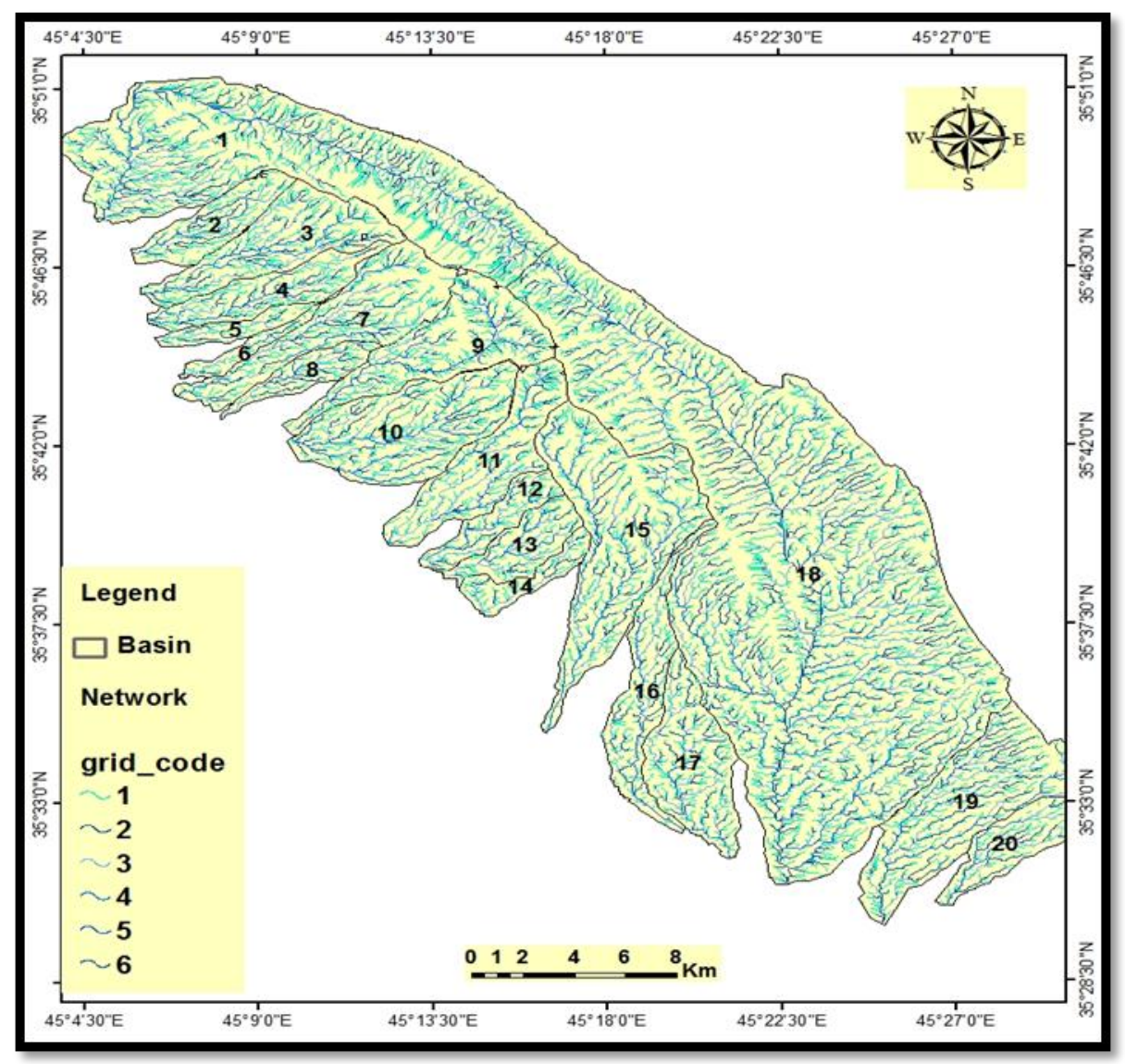

Fig. 4: The Drainage Basin of the Study Area Divided to Twenty Secondary Sub-Basins. 


\section{Mountain - Front Sinuosity $\left(\mathbf{S}_{\mathrm{mf}}\right)$ :}

This index represents a balance between stream erosion processes tending to cut some parts of mountain front and active vertical tectonics that tend to produce straight mountain fronts. Mountain front sinuosity is defined by the equation:

$$
\mathrm{S}_{\mathrm{mf}}=\mathrm{L}_{\mathrm{mf}} / \mathrm{L}_{\mathrm{s}}
$$

Where: $S_{m f}$ is the mountain-front sinuosity; $L_{m f}$ is the length of the mountain front along the foot of the mountain, at the severe break in slope; and Ls is the straightline length of the mountain front (Keller and Pinter, 2002) (Bety, 2015) (Fig .5).

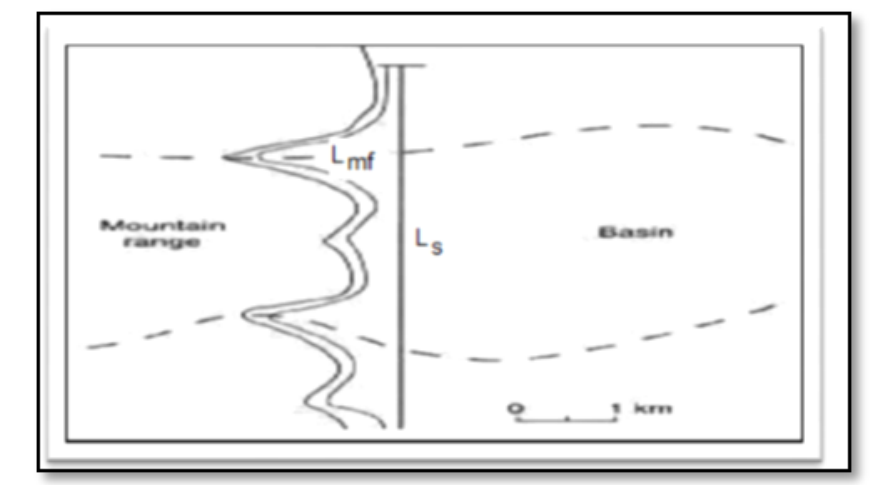

Fig. 5: Calculation of Mountain Front Sinuosity (Keller and Pinter,2002).

The description of mountain front sinuosity with their classes and degrees was set in the Table (1) (Arian, and Aram, 2014). The results of the $S_{\mathrm{mf}}$ factor for the study area was acquired and classified into the three main categories as shown in the Table (2).

Table 1: The Categories of the Mountain $S_{\mathrm{mf}}$ (Arian and Aram, 2014).

\begin{tabular}{|l|l|l|l|}
\hline Value of $\mathrm{S}_{\mathrm{mf}}$ & Description & Class & Degree \\
\hline $1.0-1.6$ & Active mountain front & 1 & High \\
\hline $1.6-3.0$ & Lesser activity & 2 & Moderate \\
\hline $3-5$ & Inactive mountain - fronts & 3 & Low \\
\hline
\end{tabular}


Table 2: The Results of the $\mathrm{S}_{\mathrm{mf}}$ Within Study Area.

\begin{tabular}{|r|r|r|r|r|r|}
\hline Basin & $\mathbf{L}_{\mathbf{M F}}$ & $\mathbf{L}_{\mathbf{S}}$ & $\mathbf{S}_{\mathbf{M F}}$ & class & Degree \\
\hline 1 & 16372 & 16024 & 1.02 & 1 & High \\
\hline 2 & 1669 & 1633 & 1.02 & 1 & High \\
\hline 3 & 4518 & 4160 & 1.08 & 1 & High \\
\hline 4 & 1880 & 1851 & 1.01 & 1 & High \\
\hline 5 & 976 & 958 & 1.01 & 1 & High \\
\hline 6 & 678 & 663 & 1.02 & 1 & High \\
\hline 7 & 4066 & 3686 & 1.10 & 1 & High \\
\hline 8 & 1376 & 1362 & 1.01 & 1 & High \\
\hline 9 & 5252 & 5001 & 1.05 & 1 & High \\
\hline 10 & 3132 & 3067 & 1.02 & 1 & High \\
\hline 11 & 2600 & 2355 & 1.10 & 1 & High \\
\hline 12 & 1738 & 1724 & 1 & 1 & High \\
\hline 13 & 1780 & 1757 & 1.01 & 1 & High \\
\hline 14 & 1297 & 1270 & 1.02 & 1 & High \\
\hline 15 & 8372 & 7955 & 1.05 & 1 & High \\
\hline 16 & 2830 & 2802 & 1 & 1 & High \\
\hline 17 & 5508 & 5480 & 1 & 1 & High \\
\hline 18 & 28791 & 27748 & 1.03 & 1 & High \\
\hline 19 & 4873 & 4775 & 1.02 & 1 & High \\
\hline 20 & 2168 & 2125 & 1.02 & 1 & High \\
\hline
\end{tabular}

\section{The stream length-gradient index (SL):}

The SL index remains approximately constant along a graded stream, and variations in the SL index appear to be attributed to tectonic or to structural and lithological controls (Hack, 1957).

The stream length-gradient index SL is calculated by using the formula:

$\mathrm{SL}=(\Delta \mathrm{H} / \Delta \mathrm{L}) \mathrm{L}$

where $\Delta \mathrm{H} / \Delta \mathrm{L}$ is the channel slope or gradient of the reach, $(\Delta \mathrm{H})$ is the change in elevation of reach and $\Delta \mathrm{L}$ is the length of reach, and $\mathrm{L}$ denotes the total upstream length (Fig. 6).

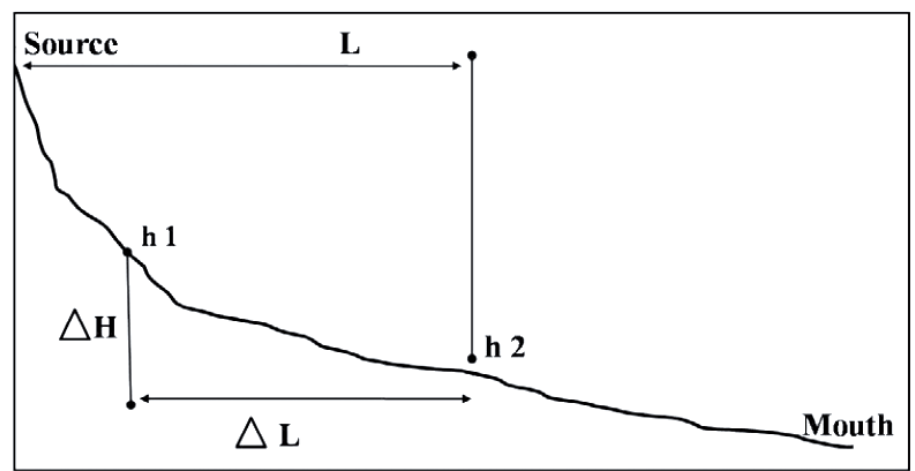

Fig. 6 : Showing the Calculation of the SL Index. 
These parameters are measured by topographic maps and digital elevation model (DEM), this index is calculated along the master river. The values of SL index were classified into three categories (El Hamdouni, el at., 2008), shown in table (3). The results of the SL factor for the study area was acquired and classified into three main categories as shown in the Table (4).

Table 3 : The categories of the (SL) (El Hamdouni, el at, 2008).

\begin{tabular}{|l|l|l|}
\hline Range & Class & \multicolumn{1}{|c|}{ Degree } \\
\hline$(\mathrm{SL} \geq 500)$, & 1 & High \\
\hline $300 \leq \mathrm{SL}<500)$ & 2 & Moderate \\
\hline$(\mathrm{SL}<300)$ & 3 & low \\
\hline
\end{tabular}

Table 4: The Results of the SL Within Study Aarea.

\begin{tabular}{|l|l|l|l|l|l|r|}
\hline Basin & L & $\Delta \mathbf{H}$ & $\Delta \mathbf{L}$ & SL & Class & Degree \\
\hline 3 & 19164 & 25 & 789 & 607,22 & 1 & High \\
\hline 2 & 6983 & 39 & 883 & 308.42 & 2 & Moderate \\
\hline 4 & 9936 & 27 & 857 & 313.03 & 2 & Moderate \\
\hline 9 & 12546 & 46 & 1347 & 428.44 & 2 & Moderate \\
\hline 10 & 10788 & 23 & 711 & 348.97 & 2 & Moderate \\
\hline 15 & 14107 & 38 & 1678 & 319.46 & 2 & Moderate \\
\hline 18 & 32548 & 23 & 2191 & 341.67 & 2 & Moderate \\
\hline 20 & 6953 & 39 & 879 & 308.49 & 2 & Moderate \\
\hline 1 & 21429 & 5 & 956 & 112.07 & 3 & Low \\
\hline 5 & 5662 & 18 & 706 & 144.35 & 3 & Low \\
\hline 6 & 5780 & 20 & 840 & 137.61 & 3 & Low \\
\hline 7 & 11484 & 26 & 1091 & 273.67 & 3 & Low \\
\hline 8 & 6753 & 11 & 545 & 136.29 & 3 & Low \\
\hline 11 & 10163 & 26 & 1447 & 182.12 & 3 & Low \\
\hline 12 & 6861 & 6 & 561 & 73.37 & 3 & Low \\
\hline 13 & 6062 & 11 & 884 & 75.43 & 3 & Low \\
\hline 14 & 5567 & 22 & 842 & 145.45 & 3 & Low \\
\hline 16 & 15767 & 12 & 1937 & 97.67 & 3 & Low \\
\hline 17 & 10532 & 9 & 1078 & 87.92 & 3 & Low \\
\hline 19 & 10581 & 16 & 1584 & 106.87 & 3 & Low \\
\hline
\end{tabular}

\section{Ratio of valley floor width to valley height $\left(V_{f}\right)$ :}

The Valley Width-to-Height Ratio $\left(V_{f}\right)$ allows comparison of erosional patterns between watersheds. The watershed in this case is the unit of measure; one $\mathrm{V}_{\mathrm{f}}$ value per watershed.

The index was originally used to distinguish $\mathrm{V}$-shaped valleys from U-shaped valleys, where $\mathrm{V}$-shaped valleys are common in areas of active uplift and deep, linear stream incision (low $\mathrm{V}_{f}$ values, often close to 0 ). U-shaped valleys are 
representative of formerly glaciated or tectonically stable areas where stream valley bottoms tend to be wider (higher $\mathrm{V}_{f}$ values).

The ratio of valley floor width to valley height $\left(V_{f}\right)$ can be expressed as

$$
V_{f}=2 \mathrm{~V}_{\mathrm{fw}} /\left(\mathrm{E}_{\mathrm{ld}}-\mathrm{Esc}\right)+\left(\mathrm{E}_{\mathrm{rd}}-\mathrm{E}_{\mathrm{sc}}\right)
$$

where $V_{f}$ is the valley floor width to height ratio; $\mathrm{V}_{\mathrm{fw}}$ is the width of valley floor; $E_{l d}$ and $E_{r d}$ are elevations of the left and right valley divides respectively and $E_{s c}$ is the elevations of the valley floor (Bull and McFadden, 1977). (Fig. 7). Table (5) shows the categories of Vf according to Bull and Mcfadden (1977). The results of the $\mathrm{V}_{\mathrm{f}}$ factor for the study area is acquired and classified into three main categories as shown in Table (6).

Table 5: The Categories of $V_{f}$, (Bull and Mcfadden, 1977).

\begin{tabular}{|l|l|l|}
\hline Range & Class & Degree \\
\hline$<0.5$ & 1 & High \\
\hline $0,5-1$ & 2 & Moderate \\
\hline$>1$ & 3 & Low \\
\hline
\end{tabular}

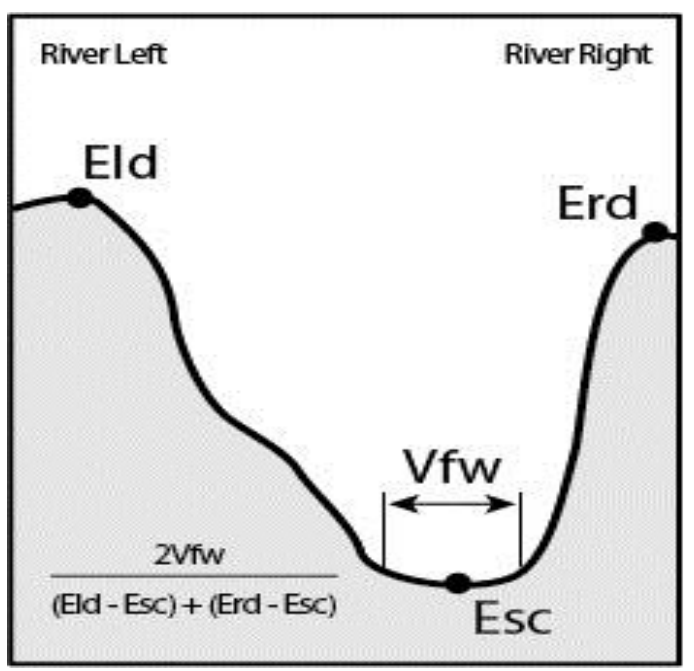

Fig. 7: The Four Inputs to the Valley Width to Height Ratio Equation (Bull and Mcfadden, 1977). 
Table 6 :The $\mathrm{R}$ of $\mathrm{V}_{\mathrm{f}}$ in Study Area.

\begin{tabular}{|c|c|c|c|c|c|c|c|}
\hline Basin & $\mathbf{V f w}(\mathbf{m})$ & $\mathbf{E s c}(\mathbf{m})$ & Erd(m) & Eld(m) & Vf & class & Degree \\
\hline 1 & 43 & 1170 & 1323 & 1365 & 0.24 & 1 & High \\
\hline 4 & 28 & 1140 & 1220 & 1182 & 0.45 & 1 & High \\
\hline 15 & 39 & 1319 & 1470 & 1448 & 0.27 & 1 & High \\
\hline 18 & 106 & 1140 & 1380 & 1638 & 0.28 & 1 & High \\
\hline 3 & 40 & 1102 & 1194 & 1141 & 0.61 & 2 & Moderate \\
\hline 7 & 24 & 982 & 1033 & 1014 & 0.6 & 2 & Moderate \\
\hline 11 & 10 & 894 & 904 & 905 & 0.95 & 2 & Moderate \\
\hline 12 & 34 & 960 & 982 & 1022 & 0.8 & 2 & Moderate \\
\hline 2 & 95 & 880 & 885 & 882 & 27.14 & 3 & Low \\
\hline 5 & 37 & 845 & 851 & 853 & 5.28 & 3 & Low \\
\hline 6 & 17 & 839 & 850 & 846 & 1.88 & 3 & Low \\
\hline 8 & 42 & 875 & 884 & 889 & 3.65 & 3 & Low \\
\hline 9 & 20 & 821 & 823.5 & 823 & 8,8 & 3 & Low \\
\hline 10 & 30 & 920 & 940 & 945 & 1.3 & 3 & Low \\
\hline 13 & 43 & 968 & 984 & 976 & 3.58 & 3 & Low \\
\hline 14 & 30 & 950 & 964 & 961 & 2.4 & 3 & Low \\
\hline 16 & 38 & 1050 & 1057 & 1063 & 3.8 & 3 & Low \\
\hline 17 & 120 & 758 & 774 & 772 & 8 & 3 & Low \\
\hline 19 & 43 & 839 & 846 & 852 & 4.5 & 3 & Low \\
\hline 20 & 55 & 1097 & 1172 & 1130 & 1.04 & 3 & Low \\
\hline
\end{tabular}

\section{Active Tectonics Index (Iat):}

Iat index is achieved from the average of different geomorphic indicator classes according to the following equation:

$$
\text { Iat }=\mathrm{S} \backslash \mathrm{N}
$$

S: Total classes geomorphic indicators that is calculated, N: Number of indicators.

For the purpose of establishing the final classification of the extension of the study area affected by tectonic activity, the combined analyzed indices represent the relative active tectonics (Iat). The area is divided into four regions as classes according to the values of Iat. These classes are class 1 (of very high activity), class 2 (of high activity), class 3 (of moderate activity), and class 4 (of low activity). The regions with relatively high tectonic activity correspond mostly to the active structures in the basin (Eynoddin, 2017) which are shown in Table (7). 
Table 7: The Categories of IAT Classification (Eynoddin,2017).

\begin{tabular}{|l|l|l|}
\hline Degree & Class & Range \\
\hline Very High & 1 & $1<$ IAT $\leq 1.5$ \\
\hline High & 2 & $1.5<$ IAT $\leq 2$ \\
\hline Moderate & 3 & $2<$ IAT $\leq 2.5$ \\
\hline Low & 4 & $2.5<$ IAT \\
\hline
\end{tabular}

To explain the effect of tectonic activity for each index of the prior indicators alone, results are collected for all indicators in one table (Table 8), in order to produce a final map, which shows the final combination of the tectonic activity indicators to explain the distribution of tectonic activity in the study area (Fig. 8).

Table 8: The Iat Classes of Tectonic Activity in the Study Area.

\begin{tabular}{|l|l|l|l|l|l|l|l|}
\hline Basin & SL & $\mathbf{V}_{\mathbf{f}}$ & $\mathbf{S M F}$ & $\mathbf{I A T}$ & $\mathbf{S} / \mathbf{N}$ & $\begin{array}{l}\text { CLASS } \\
\text { LAT }\end{array}$ & Degree \\
\hline 3 & 1 & 2 & 1 & 4 & 1.3 & 1 & $\begin{array}{c}\text { Very } \\
\text { High }\end{array}$ \\
\hline 4 & 2 & 1 & 1 & 4 & 1.3 & 1 & $\begin{array}{c}\text { Very } \\
\text { High }\end{array}$ \\
\hline 15 & 2 & 1 & 1 & 4 & 1.3 & 1 & $\begin{array}{c}\text { Very } \\
\text { High }\end{array}$ \\
\hline 18 & 2 & 1 & 1 & 4 & 1.3 & 1 & $\begin{array}{c}\text { Very } \\
\text { High }\end{array}$ \\
\hline 1 & 3 & 1 & 1 & 5 & 1.6 & 2 & High \\
\hline 2 & 2 & 3 & 1 & 6 & 2 & 2 & High \\
\hline 7 & 3 & 2 & 1 & 6 & 2 & 2 & High \\
\hline 9 & 2 & 3 & 1 & 6 & 2 & 2 & High \\
\hline 10 & 2 & 3 & 1 & 6 & 2 & 2 & High \\
\hline 11 & 3 & 2 & 1 & 6 & 2 & 2 & High \\
\hline 12 & 3 & 2 & 1 & 6 & 2 & 2 & High \\
\hline 20 & 2 & 3 & 1 & 6 & 2 & 2 & High \\
\hline 5 & 3 & 3 & 1 & 7 & 2.3 & 3 & Moderate \\
\hline 6 & 3 & 3 & 1 & 7 & 2.3 & 3 & Moderate \\
\hline 8 & 3 & 3 & 1 & 7 & 2.3 & 3 & Moderate \\
\hline 13 & 3 & 3 & 1 & 7 & 2.3 & 3 & Moderate \\
\hline 14 & 3 & 3 & 1 & 7 & 2.3 & 3 & Moderate \\
\hline 16 & 3 & 3 & 1 & 7 & 2.3 & 3 & Moderate \\
\hline 17 & 3 & 3 & 1 & 7 & 2.3 & 3 & Moderate \\
\hline 19 & 3 & 3 & 1 & 7 & 2.3 & 3 & Moderate \\
\hline & & & & & & & \\
\hline
\end{tabular}




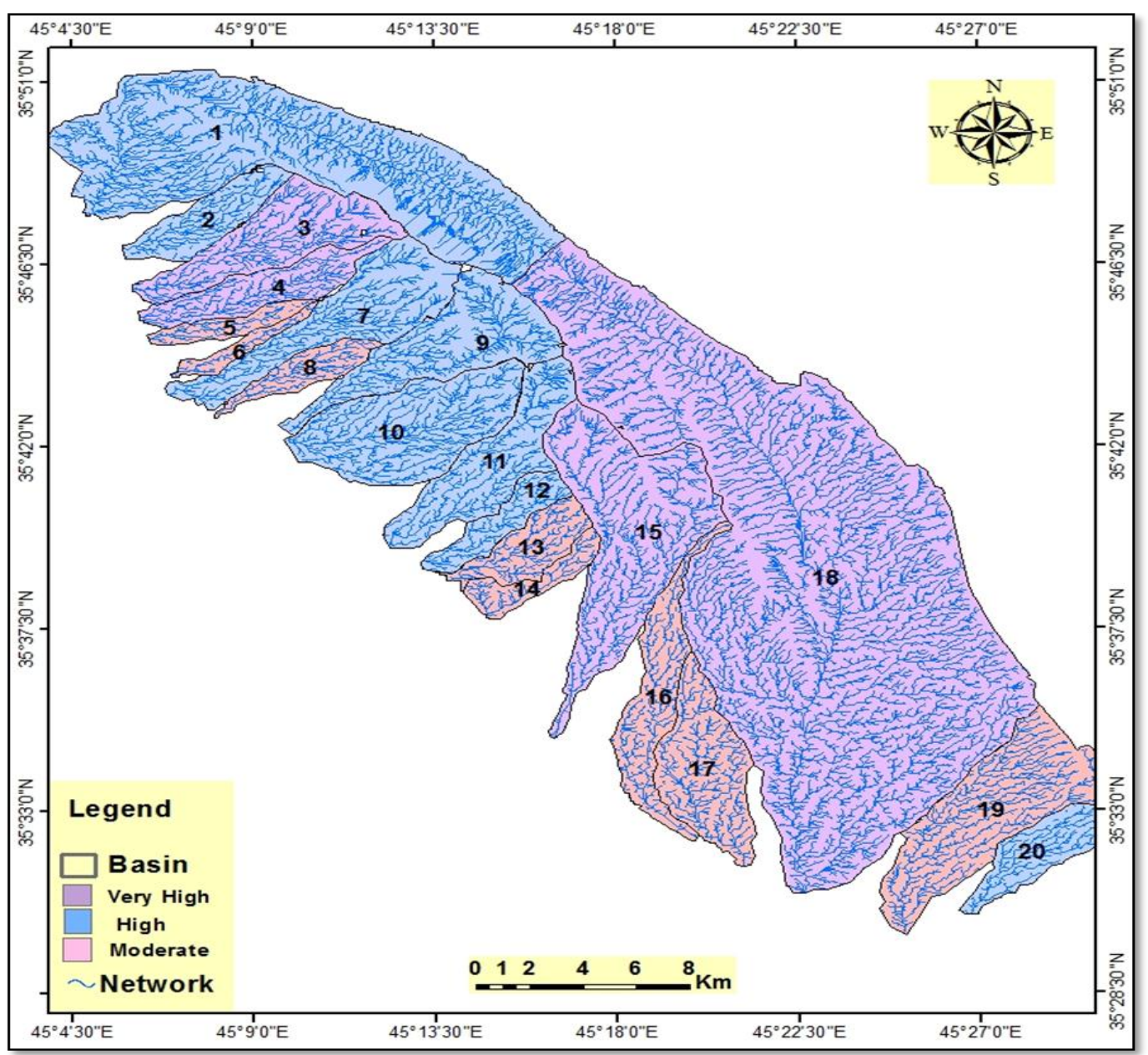

Fig. 8: The IAT Classes of Tectonic Activity in the Study Aarea.

\section{Discussion of Results}

The study area located at northeastern part of Iraq. iits known to be tectonically an active area due to its position in the northeastern marginal part of the Arabian Plate, which is in collision with the Eurasian (Iranian) Plate. Thus, the whole area that referred to the High Folded Zone is consequently active, and then discussion of geomorphical indicators of a neo-tectonic activity such as mountain front sinuosity, the stream length-gradient index and ratio of valley floor width to valley height shows that the area is submitted to high tectonic activities.

Mountain front sinuosity $\left(\mathrm{S}_{\mathrm{mf}}\right)$ represents a balance between stream erosion processes tending to cut some parts of mountain front and active vertical tectonics that tend to produce straight mountain fronts. The index value $\left(\mathrm{S}_{\mathrm{mf}}\right)$ is less than (1.6) within study area; it indicates to the active tectonic processes. The stream length - gradient index (SL) is used to identify recent tectonic activity by identifying anomalously high index values on particular soft rock type of an area of high SL indices may indicate recent tectonic activity. SL index values are relatively low in the study area, indicating that the rock type is soft.

The valley floor width-valley height ratio $(\mathrm{V} f)$ differentiates between broad floored canyons and $\mathrm{V}$ - shaped valleys. Low values of $(\mathrm{V} f)$ in the study area is associated with active tectonism. 


\section{CONCLUSION}

Geomorphic indices provide useful tools for studying intensity of tectonic activity.

1- GIS techniques are proved as highly efficient in the analysis and interpretation of the results.

2- Drainage networks have been extracted automatically from DEMs.

3- The study area is located within the High Folded Zone, where several major and minor anticlines and thrust faults exist within.

4- The area is generally affected by modern tectonic activity according to the results obtained by geomorphological factors.

\section{REFERENCES}

Arian, M. and Aram, Z., 2014. Relative Tectonic Activity Classification in the Kermanshah Area, Western Iran. Solid Earth, Vol. 5, pp. 1277 - 1291.

Bety, K. A., 2015. Geomorphic indexes of tectonic activity through the analysis of the drainage systems in the Sangaw area, Kurdistan Region-NE Iraq. Journal of Zankoi Sulaimani, Vol. 17 - 1 (Part - A).

Bull, W.B., and L.D. McFadden, "Tectonic geomorphology north and south of the Garlock fault, California. In D.O.Doehring(ed), Geomorphology in Arid Regions" Proceedings of the Eighth Annual Geomorphology Symposium. Binghamton, NY: State University of New York at Binghamton, 115 - 138. (In Keller and Pinter, 2002).

Burbank, D.W. and Anderson, R.S., 2001. Tectonic Geomorphology. Blackwell Science, Malden, MA.

El Hamdouni, R., Irigaray C., Fernández T., Chacón J., Keller E.A., 2008. Assessment of relative active tectonics, southwest border of the Sierra Nevada (southern Spain),. Geomorphology, Vol. 96, No. 1 - 2, pp.150 - 173. Eynoddin, E.H, Solgi,A., Pourkermani, M., Matkan, A., Arian, M., 2017. Assessment of Relative Active Tectonics in the Bozgoush Basin (SW of Caspian Sea). Open Journal of Marine Science, Vol. 7, pp. 211 - 237.

Fouad, S.F., 2010. Tectonic map of Iraq, scale 1:1000000, 3rd.GEOSURV, Baghdad, Iraq.

Hack, J.T., 1957. Studies of Longitudinal Stream Profiles in Virginia and Maryland. United States Geological Survey Professional Paper, Vol. 259 B, Reston, pp. 45 - 97.

Jassim, S.Z. and Goff, J.C., 2006. Geology of Iraq. Dolin, Prague and Moravian Museum, Brno.

Keller. E.A. and Pinter, N, 2002. Active Tectonics-Earthquakes, Uplift, and Landscape, Second Ed. Prentice Hall, Inc. New Jersey, USA, 362p .

Sissakian, V.K. and Fouad, S.F., 2014. Geological Map of Sulaimaniyah Quadrangle, scale 1: 250 000, 2nd ed., Iraq Geological Survey (GEOSURV) Publications, Baghdad, Iraq. 